\title{
Rola zasad estetycznych w procesie projektowania konstrukcji mostowych
}

\author{
Krzysztof Śledziewski \\ Katedra Dróg i Mostów, Wydział Budownictwa i Architektury, Politechnika Lubelska, \\ e-mail: k.sledziewski@pollub.pl
}

Streszczenie: Projektowanie konstrukcji mostowych jest problemem inżynierskim. Spośród wielu istotnych aspektów, decydującą rolę odgrywają bezpieczeństwo, technologia wykonania oraz ekonomia. Niestety aspekt estetyczny jest często pomijany. Należy jednak pamiętać, że zrozumienie wraz z pełnym uwzględnieniem zasad estetycznego ukształtowania mostu jest konieczne zarówno w początkowej fazie projektowania, jak i w fazie końcowej. Zasady te są przydatne, jako wytyczne komponowania i zestawienia elementów obiektu w całość przy jednoczesnym sprawdzeniu koncepcji.

Słowa kluczowe: estetyka, projektowanie, mosty, konstrukcje.

\section{Wprowadzenie}

Pojęcie estetyki mostów związane jest z uczuciami wyższego rzędu, z którymi mamy do czynienia od najdawniejszych czasów [1]. Względy estetyczne towarzyszą funkcjonalności obiektów, kształtują przestrzeń, wzbudzając uczucie harmonii nie tylko ze względu na wygląd, wpływają również na psychikę i kulturę człowieka. Budowa mostów to także sztuka, do której należy przykładać szczególną uwagę, gdyż obiekty mostowe stają się trwałymi elementami środowiska i „towarzyszą” nam przez wiele dziesiątków lat.

Inżynieria mostowa $\mathrm{w}$ ostatnim czasie zdominowana została przez rozwój techniki i czynniki ekonomiczne [2]. Mosty stały się odzwierciedleniem rozwoju cywilizacyjnego społeczeństwa [3]. Miano „estetycznego ukształtowania” obecnie rozumiane jest bardzo szeroko. Nie chodzi tylko o piękno obiektu samo w sobie ale również o zachowanie podstawowych zasad formy. Most zarówno ze strony funkcjonalności, jak i materiałowej oraz konstrukcyjnej powinien być dostosowany do otoczenia i nie ingerować w żaden sposób w otaczające go środowisko. Mało tego powinien być w harmonii a czasem nawet wzbogacać otoczenie. Należy pamiętać aby idące z biegiem czasu zmiany nie wpływały negatywnie na jego odbiór. Mosty są obiektami bardziej zadziwiającymi niż inne elementy architektury. Są rozpowszechnione i dostępne jako dzieło nawet dla tych, którzy nie interesują się sztuką. Posiadają swój indywidualny charakter. Pełnią nie tylko funkcję komunikacyjną ale również i społeczną [4].

W poniższym artykule przedstawiono kształtowanie się pojęcia estetyki w odniesieniu do konstrukcji mostowych. Przedstawiono w dużym skrócie jej główne założenia oraz aspekty architektoniczno - konstrukcyjnego projektowania mostów wraz z czynnikami jakie wpływają na ich odbiór estetyczny. 


\section{Pojęcie estetyki}

Estetykę definiuje się jako naukę o przedmiotach pięknych i sztuce, która zawiera również rozważania na temat przeżyć estetycznych. Estetyka europejska miała swój początek w starożytnej Grecji i rozwija się aż do czasów dzisiejszych. Jej rozwój jest ciągły, niestety nie pozbawiony nasileń i zahamowań oraz zwrotów i załamań. Najbardziej gwałtowne zwroty nastąpiły po upadku Cesarstwa Rzymskiego oraz w dobie Odrodzenia. Zmiany te wpłynęły nie tylko na samą estetykę ale również na całą kulturę europejską. Zdarzenia te pozwoliły wyodrębnić trzy okresy estetyki: starożytny, średniowieczny i nowożytny [5].

Estetyka starożytna obejmuje blisko tysiąc lat i stanowi fundament estetyki europejskiej. W przeważającej części była dziełem Greków a w późniejszym okresie do jej rozwoju przyczyniły się również inne narody.

Pojęcia estetyki Greków były jednym ze źródeł estetyki, które częściowo ukształtowały się przed erą fillozofów i znacznie różnią się od tych, jakie potocznie używa się dziś. Wyraz „piękno” oznaczało wszystko co budzi uznanie. Przede wszystkim pojęcie piękna było szerokie i ogólnikowe. Obejmowało nie tylko widoki i dźwięki, ale także np. cechy charakteru. Grecy pojęcie piękna nazywali dobrem materialnym i intelektualnym. Zakłada się, że to oni byli twórcami Wielkiej Teorii. Platon uważał, że piękno było czymś dla czego warto żyć i stawiał je obok prawdy i dobra. Dało to początek trzem największym wartościom: prawda, dobro i piękno. Ta triada od tej pory utrzymywała się w myśli europejskiej. Piękno polegało na doborze proporcji i jest stosunkiem najprostszych liczb. W muzyce Grecy posługiwali się przede wszystkim oktawą (1:2) i kwintą (2:3), szczególnie w ciele ludzkim odnajdywali proporcje 1:8 i 1:3, a w samej architekturze - 5:8 [6]. „Każda dziedzina sztuki ma swoiste dla siebie rodzaje stosunków między elementami budującymi dzieło sztuki. Tak więc na przykład w architekturze stosunki są przestrzenne, natomiast w muzyce czasowe. W mostownictwie, podobnie jak w architekturze, o pięknie mostu decydują głównie liczba i rozpiętości przęseł oraz smukłości podpór i ustroju nośnego" [4].

W Średniowieczu zachowały się teoria i pogląd na piękno ze starożytności. Święty Augustyn uważał, że rzeczy piękne są piękne same przez się, a nie dlatego, że się komuś podobają. Według jego formuły piękno to miara, kształt i ład (modus, species, ordo). Od czasów Becjusza, czyli od IV wieku pochodzi średniowieczna formuła piękna: współmierność członków (membronum cemmensuratio). Teoria piękna w średniowieczu była dualistyczna. Jedni twierdzili, że podstawą piękna są proporcje, inni, że do pojęcia piękna, należy jasność i właściwa proporcja. Uważano, że wszystko pochodzi z woli Bożej, dzieło rodzi się w duszy artysty, jego narzędziach i ukształtowaniu materii.

Okres odrodzenia stanowił powrót do teorii piękna ze starożytności, piękna jako miary, kształtu i ładu. Leonardo da Vinci uważał, że piękno jest spostrzegane nie tylko przez nasze zmysły, ale też odbierane przez umysł. Harmonia była najwyższym wyrazem piękna. Wielu filozofów rozważało problem piękna dochodząc do nowych spostrzeżeń. W. Tatarkiewicz w swoich dziełach dokonał prezentacji tych spostrzeżeń [1].

W XIX wieku wyłoniły się dwie teorie piękna: pierwsza głoszona przez Hegla- piękno jest objawieniem idei, druga głoszona przez Crocego - piękno jest wyrazem psychiki. Przekonanie o subiektywności piękna doprowadziło to wytworzenia poglądu, że nie piękno jest podstawowym pojęciem estetyki a przeżycia estetyczne. W obecnych poglądach wyłoniły się dwa nurty: estetyka ekspresji i estetyka kontemplacji. Najważniejsze jest wyrażanie przez sztukę życia wewnętrznego - każda forma jest wyrazem treści duchowych (jak pisał Kandinsky).

XX wiek przyniósł porzucenie klasycznych reguł piękna i w konsekwencji rezygnację z mistrzostwa wykonania. Symetria, równowaga, zwartość, jedność zastąpione są asymetrią, 
a równowaga staje się chwiejna. Powstaje dekompozycja. Zachodzi integracja gatunków i rodzajów sztuki oraz wykorzystanie rozwoju technicznego. Estetyka staje się uogólniona. Pojawiają się konwencje awangardowe i artystyczne prowadzące do odbioru estetyki wywołując szok lub prowokację.

\section{Odczucia estetyczne}

Zarówno w architekturze jak i budownictwie występują uczucia w działaniach koncepcyjnych, projektowych, w użytkowaniu budowli. Ich intensywność oraz zakres zależy od różnych czynników wpływających w większym bądź mniejszym stopniu na projektanta, użytkownika - odbiorcę.

\subsection{Czynniki wpływające na odczucia}

W uczuciach architektonicznych można wyodrębnić trzy procesy: wyobrażenia spostrzegawcze, sądy realizacyjne i klasyfikujące (rys. 1. [5]). Każdy może być pozytywny lub negatywny.

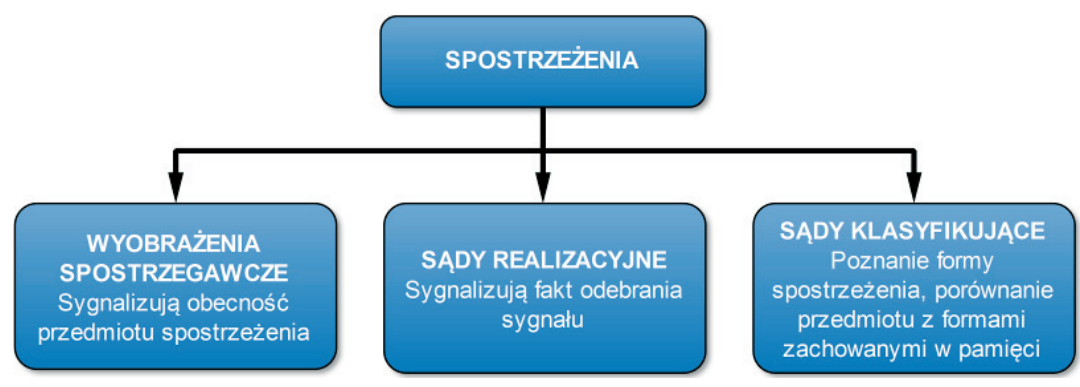

Rys. 1. Procesy uczuć architektonicznych według [5]

Spostrzeżenia wywołują zróżnicowane uczucia, które następują kolejno po sobie bądź nakładają się w różnych odstępach czasu. Nie są one zależne wzajemnie od siebie. Odbiór jakiegoś bodźca może wywoływać przyjemne uczucie, natomiast uczucia związane z sądem realizacyjnym lub klasyfikacyjnym mogą być zupełnie obojętne a nawet przykre.

\subsection{Czynniki powodujące uczucia}

Mówiąc o uczuciach architektonicznych nie można pominąc roli czynników je powodujących. Zdolność reagowania uczuciowego i spostrzegawczego może być pobudzona przez wszelkiego rodzaju:

\section{Efekt wnętrz}

Każdy człowiek znajdujący się we wnętrzu wyodrębnionym z otoczenia doznaje wrażenia, że jest ono w jakimś sensie częścią osobowości, jego bądź innych. Złudzenie to pochodzi stąd, że otoczenie spełnia nie tylko warunki funkcjonalności, ale zostało ono przez niego wybrane i dostosowane do jego potrzeb, upodobań i wyobrażeń, a w szczególności odzwierciedla wyobrażenia o samym sobie. Efekt ten nazwano zjawiskiem utożsamiania lub identyfikacji otoczenia z osobowością. Obiekty mostowe posiadają dwa wnętrza: na moście i pod mostem. Oba wnętrza są otwarte, co odróżnia je od innych budowli. Przestrzeń na moście stanowi antidotum zamkniętych pomieszczeń, świat widoczny jest $\mathrm{z}$ wysoka i całkowicie otwarty. 


\section{Kontrasty}

Kontrast pomiędzy budowlą a jej otoczeniem lub między budowlą a jej elementami zwiększa spostrzegawczość, przykuwa uwagę, zwiększa zakres bodźców a więc pobudza zdolność reagowania zarówno uczuciowego jak i spostrzegawczego. Efekt kontrastu wywołują nowe technologie, materiały lub budowle o niespotykanej skali, ekstrawagancja. Obiekty mostowe wywołują reakcje postrzegania kontrastu poprzez np. to, że widoczne są w nich płynne linie dróg lub torów. Niekiedy kontrast może wynikać z błędów związanych z celem użytkowym lub warunkami budowy. Należy mieć na uwadze fakt, że efekty kontrastu przy częstym dostrzeganiu słabną.

\section{Ekspresję}

Od czasów starożytnej Grecji uważano iż, istotą piękna architektury jest jej miarowość geometryczna. Ma ona wpływ na spostrzegawczość poprzez powtarzanie bodźców i impulsów. Spostrzeżenia wydają się bardziej czytelne a spostrzegającemu wydaje się, że ma większą sprawność. Jednak układy regularne lecz banalne wywołują negatywne odczucia - nudę. Dlatego miarowość bez dodatkowych cech nie może stanowić podstawy piękna budowli, wszelkie geometryczne, dynamiczne, funkcjonalne cechy funkcjonalności zwiększają siłę wrażeń.

\section{Zasady ksztaltowania estetycznego}

Uwzględnienie wszystkich zasad estetycznego ukształtowania mostu jest konieczne zarówno w początkowej fazie projektowania - kiedy kształtuje się formę i ogólne proporcje obiektu, jak i w fazie końcowej - gdy decyduje się o szczegółach.

Do dnia dzisiejszego nie ma gotowych szablonów bądź też wzorów opisujących jednoznacznie sposób estetycznego kształtowania. Są za to ogólne zasady, których przestrzeganie wpływa $\mathrm{z}$ reguły korzystnie na odbiór projektowanej konstrukcji. Ich znajomość w znacznym stopniu ułatwia uzyskanie poprawnych rozwiązań. Stanowią również narzędzie do weryfikacji poprawności architektonicznej na każdym szczeblu zaawansowania projektu.

\subsection{Kryteria i podstawy projektowania estetycznego}

Przegląd dotychczasowego budownictwa mostowego pozwala na zestawienie obserwacji - według powtarzalności zależności zachodzących pomiędzy elementami - i pewnych konkluzji wynikających z nich. W celu uporządkowania poszukiwań form architektonicznych, unikania zaniedbań tych opracowań a także z myślą o lepszej współpracy między projektantami, sformułowano tzw. zasady opracowywania architektury mostów. Według [5] są to:

Zasada gradacji formy - oznacza konieczność sklasyfikowania według skali i widoczności elementów. Należy przestrzegać gradacji w taki sposób aby uwaga nie była rozpraszana przez elementy nadrzędne bądź też podrzędne. Do form architektonicznych poszczególnych stopni należy wprowadzać właściwe im elementy, unikając widoczności form i elementów innych stopni. W tym celu opracowano następujące grupy form:

- efekt całości mostu i przeszkody - ma największą skalę, wynika z zasady czytelności, obiekt występuje jako całość w układzie z przeszkodą;

- droga na moście i dojazdach - istotne jest aby skala mostu nie była większa od skali drogi, w przeciwnym wypadku most traci ekspresję, lepsze wrażenie daje droga poprowadzona nad konstrukcją, a gorsze - gdy jest zasłonięta przez ustrój;

- podpory i przęsła- dostrzec można oddzielnie przęsła i podpory, ale niewidoczne są elementy, z których się składają; 
- wnętrze pod obiektem - często zaniedbywanym zagadnieniem jest wnętrze pod mostem, a jest ono bardzo istotne. Jego forma głównie zależy od wymiarów: wysokości, szerokości i długości. Korzystniej wypadają wnętrza o wysokości większej niż szerokość. Wygląd dolnych partii przęseł często pozostawiany jest bez opracowania i uzależniony tylko od rozwiązań konstrukcyjnych. Przykładem poprawnego rozwiązania tego zagadnienia jest płyta ortotropowa mostów stalowych. Inaczej sprawa się ma w przypadku mostów belkowych, w których należy wydobywać niewielkie krzywizny powierzchni dolnej płyty, zmienność grubości belek, płyt czy przepon. Takie działanie pozwala na uniknięcie efektu pustki jakie wprowadza powierzchnia płaska. Wszelkie krzywizny wprowadzają różnice załamania światła;

- detale mostowe.

Powyższa klasyfikacja jest rezultatem obserwacji form powstałych w wyniku zależności między elementami.

Zasada usuwania błędów w opracowaniu form - zasada ta jest zasadą doskonalenia formy. Powinno się usuwać z form wszystko to co uważane jest za irracjonalne.

Zasada opracowania form wszystkich elementów mostu - pozostawienie jakiegokolwiek elementu opracowania daje gorsze rozwiązanie niż dopracowanie na każdym szczeblu.

Zasada wykorzystania środków ekspresji - form architektonicznych nie można sprowadzać tylko do kształtów geometrycznych, czy też gry świateł i cieni. Powinno się również zwracać uwagę na cechy, na które jesteśmy wrażliwi. Wskazane jest korzystanie ze wszystkich dostępnych środków: kształtów konstrukcji, sił i ciężarów, świateł, cieni i barw, kształtów i zabudowy przeszkody i otoczenia, linii drogi na moście, na dojazdach i pod mostem. Należy też korzystać z cech równości, kształtów i sił, symetrii i eurytmii, proporcji poszczególnych elementów jak i całej konstrukcji, rozpiętości, wysokości i szerokości przęseł, ich podziału oraz wyposażenia mostu; wszystko to nazywamy miarowością kompozycji. Do opracowania miarowości należy korektura skażeń widoczności. Skażenia linii polegają na postrzeganiu kształtu innego niż jest w rzeczywistości. Podobnie jest z kształtami figur czy widocznością brył zależnie od barwy ich powierzchni, tła lub innych elementów obok nich położonych. Najczęściej spotykanym rodzajem skażeń wzrokowych występującym w mostownictwie jest wrażenie wygięcia ku dołowi dolnej krawędzi przęsła (rys. 2. [5]).

a)

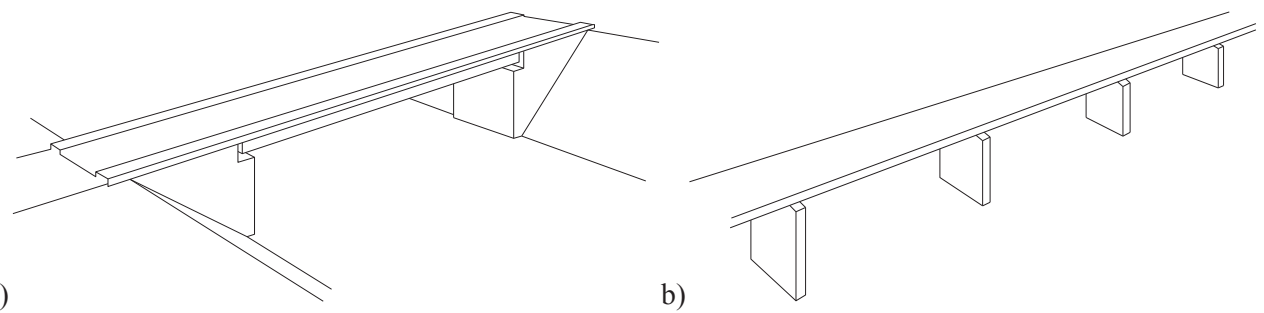

Rys. 2. Efekty wygięcia przęsła ku dołowi - efekt Zollnera: a) między krawędziami przęsła i przyczółków; b) między krawędziami przęsła i filarów [5]

Na rysunku 3 [5] pokazano właściwy sposób usunięcia efektu wygięcia krawędzi przęsła - zachowanie prostych linii ścian zewnętrznych w elewacji mostu, dając jedynie wygięcie dolnej powierzchni przęseł. 


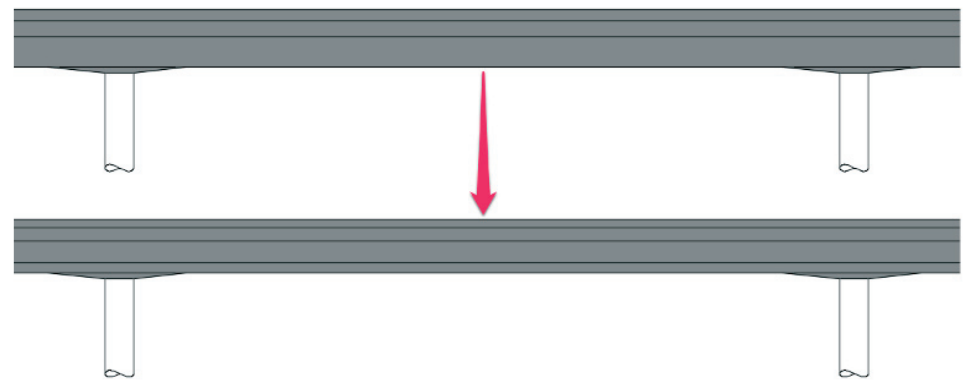

Rys. 3. Usunięcie efektu wygięcia krawędzi przęsła [5]

Pospolitym złudzeniem widoczności powierzchni jest wypukłość ścian płaskich. Najsilniej zauważane jest na słupach, mniej na powierzchniach bocznych belek i łuków. Przeciwdziałać temu można dając ścianom wklęsłe załamania, pochylenia lub wprowadzając rysunek przyległych elementów konstrukcyjnych.

Głębokość załamań wystarczająca do usunięcia złudzenia wypukłości powierzchni, powinna być rzędu od 1/10 do 1/50 szerokości ściany, pamiętając aby ścianom szerszym nadawać płytsze załamania.

Zasada pierwszeństwa form komunikacyjnych - pozwala zaprojektować z dowolną intensywnością tylko linię drogi i przeszkody pod mostem. Błędne jest przekonanie, że konstrukcja mostu jest piękna sama w sobie. Często jej forma jest zbyt intensywna i w konsekwencji zaburza czytelność całości. Do takich stwierdzeń można dojść zestawiając rozwiązania dawne ze współczesnymi (rys. 4 [7]).
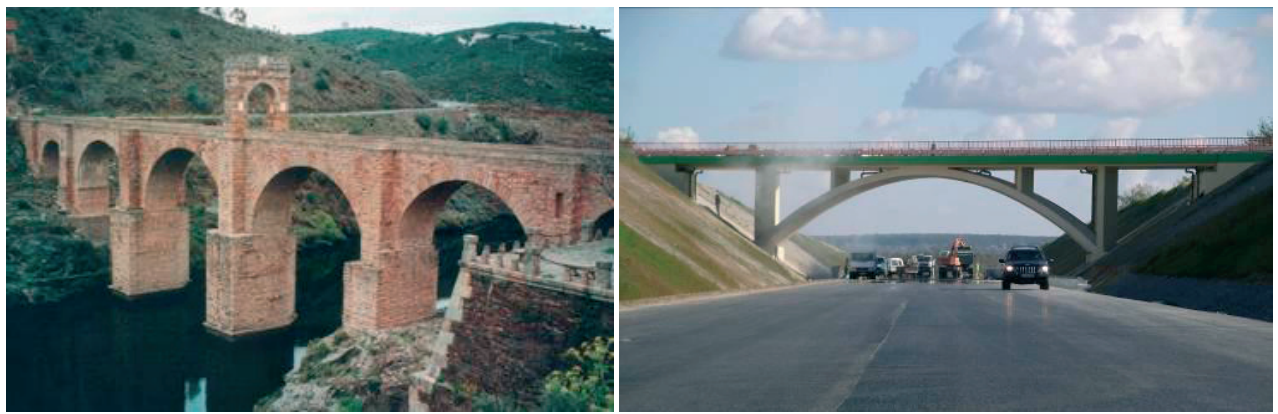

Rys. 4. Porównanie rozwiązań dawnych ze współczesnymi [7 i fot. K. Śledziewski]

Dawniej konstrukcje mostów były dość masywne, składały się z dużej ilości materiałów. Współczesne mosty są wykonane z nowoczesnych materiałów o większej wytrzymałości $[8 \div 13]$, w nowych technologiach $[14 \div 18]$, pozwalających w bardziej efektywny sposób wykorzystać przekrój [19, 20]. 

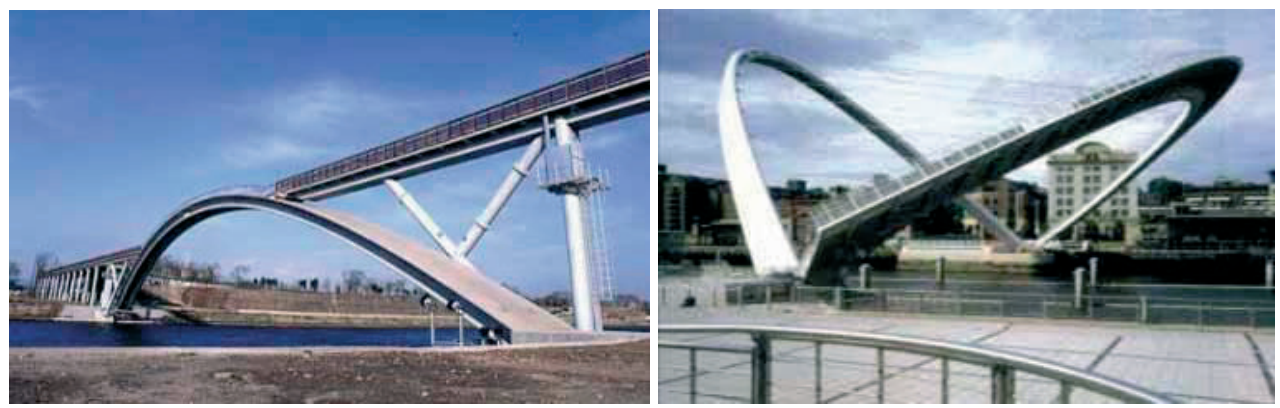

Rys. 5. Nowe formy architektoniczne mostów [21]

W nowych konstrukcjach nie ma elementów niepotrzebnych, których dawniej nie umiano usunąć (rys. 5 [21]). Dzięki temu nowe obiekty są lżejsze i widocznie mniej intensywne.

\subsection{Zasady doświadczalne architektury mostów}

Zasadami doświadczalnymi nazywamy stwierdzenia, których spostrzeżenia wpływają na przeżycia estetyczne. Są one formułowane na podstawie obserwacji prowadzonych w różnych warunkach, przez różnych obserwatorów i dotyczących szerokiego zakresu. Stanowią odmianę zasad architektonicznych, wynikają z ogólnych cech spostrzeżeń i przeżyć. Są nieskomplikowane i powszechne.

Zasady doświadczalne mogą pełnić rolę wytycznych w kompozycji architektonicznej oraz ułatwiać weryfikacje rozwiązań koncepcji. Są to dwa główne cele doświadczalnych zasad estetyki. Nie należy ich jednak traktować jako konieczne, bowiem ostatecznym sprawdzeniem jest doświadczenie. Zasady należy rozpatrywać w czworakim znaczeniu: przedmiotowym (obiektywnym), psychologicznym(subiektywnym), poznawczym i twórczym. Pierwsze dotyczy analizy form przedmiotów materialnych, drugie - odbioru przeżyć estetycznych, trzecie - wyjaśnia działania poznawcze, czwarte - wykorzystuje poznane zasady.

\subsection{Zasady wynikające ze spostrzeżeń i kojarzeń form}

Zasada całości - ,przeżycie estetyczne jest uwarunkowane dostrzegalnością wszystkich elementów formy i ich współzależności” [22]. Oznacza to, że należy dążyć do skojarzenia cech geometrycznych budowli z ich znaczeniem fizykalnym, funkcjonalnym. Zasada całości jest wielostopniowa i dotyczy analizy budowli wraz z otoczeniem, samej budowli, a także poszczególnych jej elementów. Marzyński [23] z tego względu dokonał podziału estetyki na:
a) wielką - urbanistyczną i krajobrazową,
b) średnią - architektoniczną,
c) małą - wykończenie i szczegóły.

Estetyka wielka zajmuje się usytuowaniem mostów w terenie wraz z dojazdami i dostosowaniem ich do terenu. Analizując estetykę wielką dochodzi się do zagadnień estetki średniej. Idąc dalej rozważając czynniki wpływające na odbiór wizualny mostów dochodzimy do zagadnień małej estetyki, m.in. doboru materiału czy wykończenia, które nie wpływają ani na kształt czy też konstrukcję. 

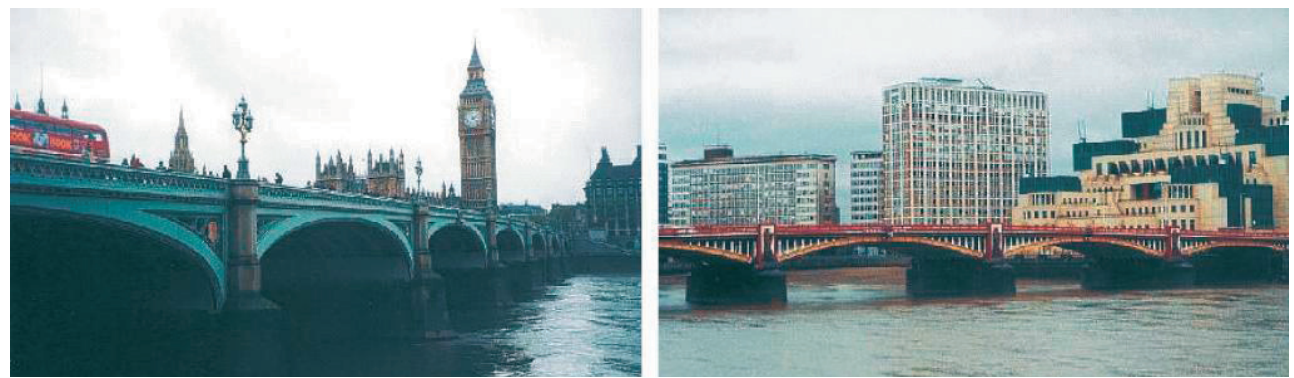

Rys. 6. Harmonia mostu z otoczeniem [24]

Chcąc zachować porządek elementów, stanowiący podstawę odbioru estetycznego należy pamiętać o spoistości formy. Musi być zachowana równowaga między elementami racjonalnymi a ekspresją architektoniczną, również brak któregokolwiek składnika wpływa ujemnie na całokształt budowli (rys. 6. [24]).

Zasada prostoty formy - zgodnie z tą zasadą liczba poszczególnych elementów mostu powinna być dostatecznie mała w celu zachowania nie skomplikowanej formy. Związane jest to bezpośrednio ze zdolnością człowieka do spostrzegania niewielkiej liczby elementów przy jednoczesnym zachowaniu prostoty formy. Kiedy forma jest zbyt złożona, człowiek nie jest w stanie dostrzec jej całości, gubi się w powiązaniach, czego efektem jest brak przeżyć estetycznych.

Zasada prostoty formy podobnie jak zasada całości jest wielostopniowa . Oznacza to, że dotyczy nie tylko całej budowli wraz z otoczeniem ale również poszczególnych elementów.

Zasady prostoty nie należy traktować jako ograniczenie ekspresji architektonicznej lub jako unikanie wyrażania istotnych zależności ale jako postulat zachowania umiaru. W konstrukcjach mostowych najbardziej wyeksponowana powinna być linia prowadzonej drogi oraz linia przeszkody, inne elementy przeprawy - mniej (rys. 7. [24]).

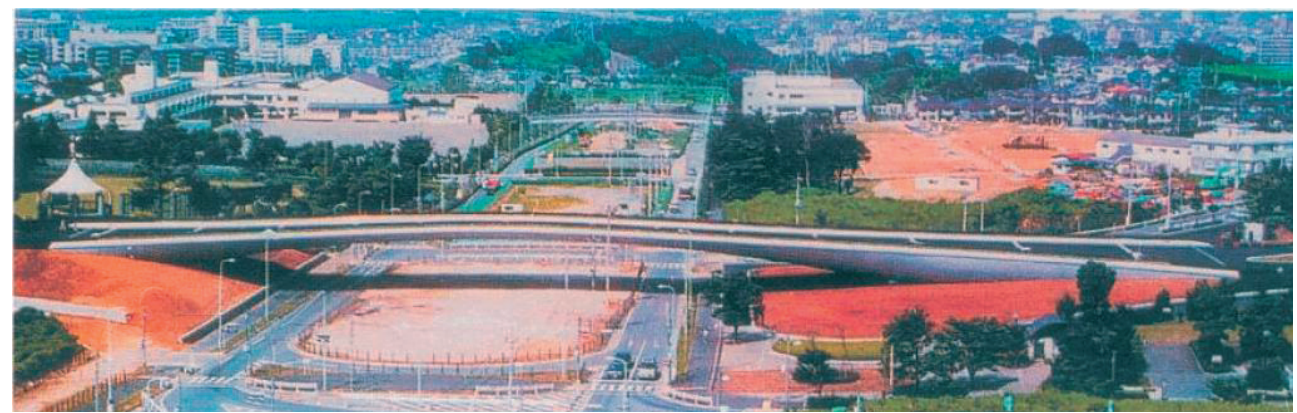

Rys. 7. Prosta forma obiektu mostowego [24]

Zasada czytelności formy - „Aby forma mogła wywoływać wrażenia estetyczne, skojarzenia jej elementów powinny być łatwo dostrzegalne” [5]. Kryterium czytelności jest uzupełnieniem dwóch poprzednich zasad. Wrażenia estetyczne są osiągane poprzez ekspresję form i łatwość skojarzenia ich ze znaczeniem poznawczym estetyki. W architekturze mostów środkiem prowadzącym do tego stanu jest stosowanie elementów nie konstrukcyjnych, dodatkowych, niekiedy wręcz przeciwstawnych. W obiektach mostowych dominują ustroje wskazujące na układ sił wewnętrznych, linie komunikacyjne, współzależność typu konstrukcji z zastosowanymi materiałami, technologią i warunkami budowy. 

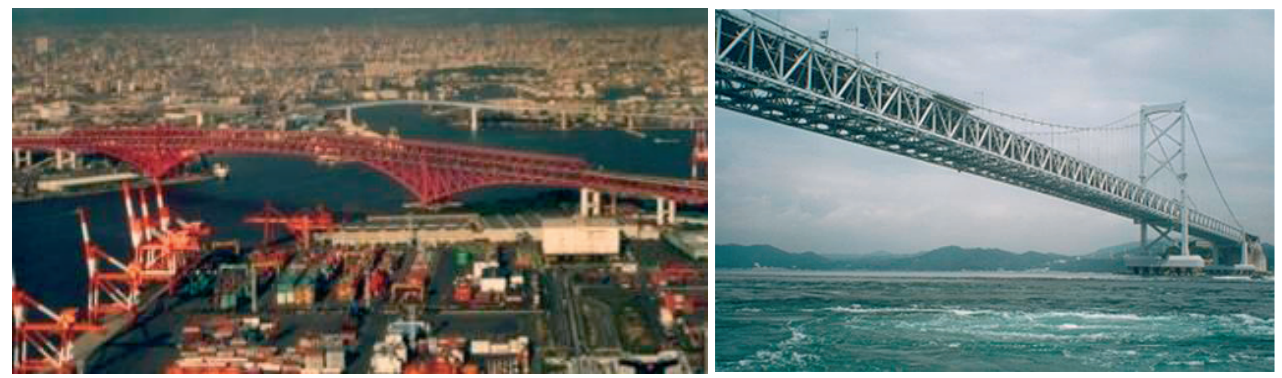

Rys. 8. Przykładowe konstrukcje kratownicowe [7]

W pierwszej połowie XX wieku wyzbyto się ekspresji tradycyjnych form architektonicznych. Ograniczono się jedynie do czytelności linii komunikacyjnych i układu sił. Nie znaczy to jednak, że układy sił same w sobie są czytelne. Przykładem mogą być mosty kratownicowe powszechnie stosowane na terenach przemysłowych ale nie tylko (rys. 8 [7]).

Siły w prętach mają różne wartości i znaki, co jest równoznaczne z brakiem czytelności. Ponieważ kryterium to jest również wielostopniowe oznacza, że formy poszczególnych elementów powinny wskazywać czy jest on ściskany, zginany itp.. W jaki sposób siły są przenoszone i przekazywane na inne ogniwa. Formy architektoniczne także muszą być czytelne pod względem przeznaczenia mostu, charakterystyki krajobrazu, warunków przyrodniczych i gospodarczych.

Zasada unikania pustki - aby mosty były ciekawe powinny zwracać na siebie uwagę, muszą one zawierać cechy przykuwające tę uwagę. Obiekty nie zawierające takich cech działają wręcz odpychająco. Pustka wzbudza uczucia analogiczne do znudzenia, osłabia zdolność działania poprzez brak pobudek emocjonalnych. Brak zależności między elementami budowli, nieudolność zrozumienia lub brak czytelności są przyczyną pustki (rys. 9 [24, 25]).
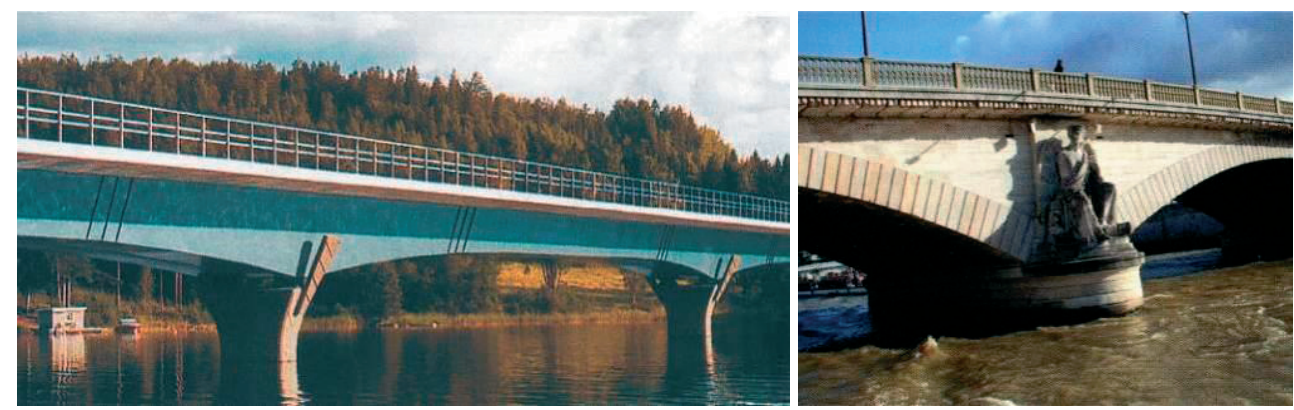

Rys. 9. Sposoby zaradzenia wrażenia pustki [24, 25]

Kryterium unikania pustki jest odmianą kryterium prawdziwości - zaprzeczenie dążenia poznawczego, pustka przemilcza prawdę, oraz czytelności formy -pusta forma jest nieczytelna. Formy, które nic nie mówią lub są niezrozumiałe należy odrzucać.

\subsection{Zasady wynikające z zależności rozumowych między elementami form}

Zasada prawdziwości formy - wymaga się aby forma wywoływała skojarzenia prawdziwe - zgodne z celem i warunkami pracy oraz funkcjonalnością i użytkowością 
obiektu. Prawdziwość jest pojęciem relatywnym w estetyce mostów i zależnym od poznania. Zależna od warunków poznania jest również trwałość tego kryterium, bowiem w zmienionych warunkach forma może okazać się nieprawdziwa.

Zasada ta powinna być używana jako nadrzędna. Obejmuje ona wnioski wynikające z celu użytkowego oraz warunków wykonania i eksploatacji budowli. Są to następujące sformułowania:

- dostosowanie mostu do celu użytkowego, dotyczy ruchu na oraz pod mostem i stanu zagospodarowania przeszkody;

- dostosowanie mostu do warunków przyrodniczych i fizykalnych, dotyczy warunków hydrologicznych i klimatycznych oraz wyboru ustroju nośnego zależnego od układu sił;

- dostosowanie mostu do warunków gospodarczych;

- dostosowanie mostu do warunków społecznych.

Zasada dostosowania do celu użytkowego - formy mostów dostosowane do celów użytkowych wpływają pozytywnie na odczucia estetyczne. Elementami najsilniej występującymi w całości budowli będąc jednocześnie najważniejszymi czynnikami są kształt drogi poprowadzonej przez most oraz dojazdy do mostu. Poprzez zastosowanie linii prostych, łuków, krzywych przejściowych, nachyleń niwelety, spadków poprzecznych dostosowujemy kształt do warunków terenowych oraz prognozowanego ruchu. Każdy z tych elementów jest dostrzegalny wzrokowo i jeśli jest zrozumiały to sprzyja wrażeniom estetycznym. Przy projektowaniu obiektu adekwatnie do celu użytkowego należy jednocześnie pamiętać o wcześniej wspomnianych kryteriach, tj.:

- zasada całości - aby droga była widziana na całym odcinku na którym jej kształt jest związany z mostem;

- zasada prostoty - aby droga nie była niepotrzebnie skomplikowana, ważne aby zastosowane rozwiązania nie były sprzeczne z ukształtowaniem terenu np. odwrotne pochylenia czy promienie;

- zasada czytelności - aby droga była widoczna w linii mostu, jednak ta zasada ma wiele znaczeń. Po pierwsze - widoczność drogi z możliwie każdego punktu zarówno spoza mostu jak i na moście. Odcinek drogi na moście wraz z dojazdami powinien tworzyć wklęsłość. W tym celu wystarczą bardzo niewielkie pochylenia nie sięgające nawet $1 \%$. Niekiedy trudno je zauważyć a mimo to mogą wpływać na walory estetyczne poprzez poprawę widoczności.

Zasada dostosowania ksztaltu ustroju do warunków fizykalnych - obiekty budowlane podlegają pewnym zależnościom przyrodniczym. Należą do nich m. in.: warunki geologiczne, roślinne, klimatyczne i fizykalne. Zwłaszcza dwie ostatnie mają szczególny wpływ na kształtowanie architektoniczne budowli. Pozostałe wpływają na rodzaj oraz jakość materiału bądź też na jego barwę i fakturę. Zasada dostosowania kształtu ustroju do warunków fizykalnych dotyczy dostosowania do układu sił oraz warunków klimatycznych (rys. 10). 


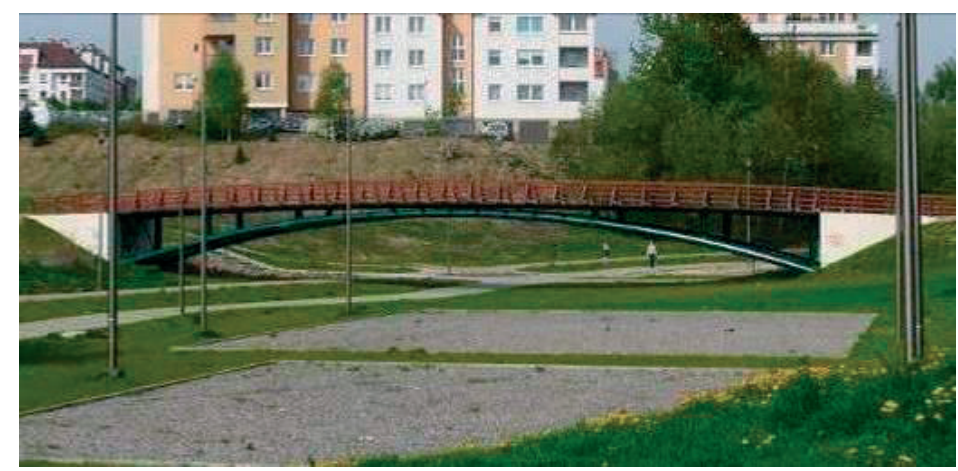

Rys. 10. Dostosowanie kształtu ustroju do warunków fizykalnych [fot. K. Śledziewski]

Zasada optymalności formy - działanie, które ma na celu najlepsze zaspokojenie potrzeb w danych warunkach nazywamy optymalnością. W odniesieniu do obiektów mostowych jest to dostosowanie ich ekspresji do warunków komunikacyjnych, budowlanych i zagospodarowania przestrzeni. Sprzyjającym czynnikiem jest optymalne doprowadzenie drogi do mostu, przeprowadzenie jej przez most, jak również dostosowanie lokalizacji, rozpiętości i wysokości mostu, układu podpór stosownie do przeszkody. Sprzeczność formy obiektu mostowego z zagospodarowaniem otoczenia wpływa ujemnie na wrażenia estetyczne.

\section{Podsumowanie}

W procesie projektowania należy dążyć do respektowania porządku, prostoty, doboru właściwych proporcji wewnętrznych i harmonii z otoczeniem. Uwzględnienie tych kilku zasad może dać naprawdę pozytywne efekty, z kolei pominięcie ich może prowadzić do dysonansu. Projektant jest zobowiązany do działania z pełną świadomością i odpowiedzialnością uwzględniając zasady estetycznego kształtowania architektonicznego konstrukcji mostowych.

Stąd też przy kształtowaniu mostów należy dążyć do zachowania smukłości zarówno całej konstrukcji jak i podpór, lekkości z zachowaniem uczucia stabilności. Prostota i ograniczenie do minimum różnorodności form podyktowana jest zasadą prostoty - czasem mniej znaczy więcej. Unikać należy ciężkich mostów wywołujących wrażenie ciężkości. Należy również starać się aby obiekt miał swoją oryginalną, niepowtarzalną formę, nadać mu charakter, coś dzięki czemu miło zapadnie w pamięci a podróż dzięki takiemu widokowi wyda się przyjemniejsza i przede wszystkim bardziej interesująca.

Przy czym pośród tysięcy budowanych obecnie obiektów bardzo trudno będzie nadać każdemu oryginalną, niepowtarzalną formę, zatem powtórzenia dobrych projektów, są rzeczą której nie da się uniknąć. Natomiast bardzo ważnym zagadnieniem jest umiejętność dopracowania szczegółów, eksponowania elementów poprawiających ogólny wygląd i maskowania detali niekoniecznie podnoszących estetykę rozwiązania.

\section{Literatura}

1 Tatarkiewicz W. Historia Estetyki, tomy: 1,2 i 3. Wydawnictwo Naukowe PWN, Warszawa, 2009.

2 Rosignoli M. Evolution of a Technique. „Concrete International”, February, 1997.

3 Kędzierski B. Postęp techniczny w mostownictwie. WKŁ, Warszawa, 1972.

4 Łagoda G. Wiadukty nad autostradami, Prace Naukowe. Budownictwo z. 137, Oficyna Wydawnicza Politechniki Warszawskiej, Warszawa, 2001. 
5 Wasiutyński Z. O architekturze mostów, Państwowe Wydawnictwo Naukowe, Warszawa, 1971.

6 Flaga K., Januszkiewicz K., Hrabiec A., Cichy -Pazder E. Estetyka konstrukcji mostowych, Wydawnictwo Politechniki Krakowskiej, Kraków, 2005.

7 Lagoda M. Materiały dydaktyczne, Politechnika Lubelska, Lublin, 2006.

8 Ajdukiewicz A. Konstrukcyjne betony cementowe nowych generacji. Inżynieria i Budownictwo, 1998, nr 9.

9 Faust T., Dehn F. Bemessungsgnmdlagen von Hochleistungsleichtbeton. Leipziger Massivbau-Seminar. „Hybrides Bauen mit Hochleistungswerkstoffen - Höhere Effizienzdurchgeschicktes Zusammenfugen”, Leipzig 2000, Teil VII.

10 Fukujama H. Fibre-Reinforced Polymers in Japan. „Structural Engineering International”, 1999, November, Vol. 9, No. 4.

11 Hubo R. HóherfesteStahleim Hoch- und Briickenbau. Leipziger Massivbau-Seminar. „Hybrides BauenmitHochleistungswer-kstoffen - HohereEffizienzdurchgeschicktes Zusammenfugen" Leipzig 2000. Teil III.

12 Radomski W. Materiał a konstrukcja - refleksje mostowca, IV Konferencja Naukowo - Techniczna „Zagadnienia materiałowe w inżynierii lądowej”, Kraków, 2003.

13 Taerwe L. Non-metallic reinforcement for concrete structures. International Conference „New Technologies in Structural Engineering", Lisbon 1997.

14 Flaga K., Pańtak M. Mosty podwójnie zespolone. Inżynieria i Budownictwo, 2006, nr 7-8.

15 Kołakowski T., Kosecki W., Marecki A. VFT® - prefabrykowane dźwigary zespolone z betonowym deskowaniem aktywnym. Inżynieria i Budownictwo, 2003, nr 3.

16 Lagoda G., Lagoda M. Nowe typy konstrukcji w mostownictwie XXI wieku. Nowoczesne Budownictwo Inżynieryjne, 2007, Lipiec - Sierpień.

17 Nakamura S. New structural forms for steel/concrete composite bridges. Structural Engineering International, 2000, Vol. 1.

18 Toczkiewicz R. Mosty typu extradosed o dźwigarach zespolonych. Drogownictwo, 2006, nr 11.

19 Rosignoli M. Prestressed Composite Box Girders for Highway Bridges. Structural Engineering International, 1997, Vol. 7.

20 Śledziewski K. Mosty PCS - nowoczesny rodzaj konstrukcji zespolonej. Inżynieria i Budownictwo, 2010, $\mathrm{nr} 8$.

21 Radomski W. Tendencje rozwojowe mostownictwa - świat i Polska. Geoinżynieria i Tunelowanie, 2005, nr 1.

22 Głomb J. Rola czynników estetycznych w procesie projektowania mostów. Zakład Narodowy im. Ossolińskich - Wydawnictwo, Wrocław, 1990.

23 Marzyński S. Estetyka mostów. Skrypt, Warszawa, 1955.

24 Łagoda G., Łagoda M. Aspekt estetyczny kształtowania obiektów mostowych. Drogi i Mosty, 2004/1.

25 Łagoda G. Piękno mostów, Mosty, 2010, nr 4.

\title{
The role of aesthetic principles in the designing process of bridge structures
}

\author{
Krzysztof Śledziewski \\ Department of Road and Bridges, Faculty of Civil Engineering and Architecture, \\ Lublin University of Technology,e-mail:k.sledziewski@pollub.pl
}

\begin{abstract}
Designing of bridge constructions is an engineering issue. Among the many aspects of relevance, safety, production technology and economy are crucial - aesthetics, regrettably, tending to be ignored. It must not be neglected, though, that full comprehending and including all the principles of aesthetic design of bridges are necessary in the initial as well as final designing phases. These rules are useful as the guidelines for composition and combining the structure's elements into a whole while checking the overall concept.
\end{abstract}

Keywords: aesthetics, designing, bridges, structures. 